Kritik af dommekraften

Immanuel Kant: Kritik af dommekraften, oversat og udgivet af Claus Bratt Østergaard, Det lille forlag, 2005, 361 sider, kr. 390,-

Kants fascinerende tredje Kritik foreligger nu i dansk oversættelse. Fascinerende er værket, fordi det helt og aldeles udspringer af et filosofisk projekt, der - som Claus Bratt Østergaard med rette fremhæver i sit forord - for længst syntes afsluttet, men som dog for dets ophavsmand viste sig at rumme et videre perspektiv, som først måtte udgrundes, før end Kant $i$ forordet til nærværende værk (1790) definitivt kunne erklære "hele mit kritiske forehavende" for tilendebragt og samtidig bebude den umiddelbart forestående 'doktrinale' fremstilling af filosofien i overensstemmelse med den forudgående kritik. Det umiddelbart overraskende i disse linier er Kants konstatering, at Kritik af dommekraften ikke vil have nogen pendant i den doktrinale fremstilling, hvor dog Kritik af den rene fornuft (1781) og Kritik af den praktiske fornuft (1788) tiltænktes rollen som modstykker til den doktrinale fremstilling af henholdsvis den faktisk aldrig fuldendte naturens metafysik og endelig sædernes metafysik.

Men hvorfor så kritisere dømmekraften? Hvis vi skal tro Kant selv i slutningen af den berømte 'Første indledning' (som oversætteren fortjenstfuldt har valgt at tage med i sin udgave), så er det "den forjættende udsigt til et fuldstændigt system for alle sindsevnerne", der har motiveret den tredje kritik. Men hvor der er tre sindsevner - erkendelsesevnen, begærsevnen og følelsen af lyst og ulyst - har filosofien i Kants systematik kun to dele - den praktiske og den teoretiske. For så vidt er det foreliggende værk, hvis første del blotlægger muligheden for de æstetiske (til forskel fra de praktiske og teoretiske) domme, som tjener som grund for vor følelse af lyst og ulyst, tilsyneladende et stykke fritsvævende kritik, men dog ikke mere, end at denne kritik faktisk tilkommer rollen at formidle mellem de to doktrinale dele af filosofien. Denne rolle tilkommer den dog, så vidt jeg kan se, ikke i og med den nævnte første del, der til gengæld grundlægger en virkningshistorisk betydningsfuld kunstteori, men derimod i kraft af den anden dels filosofisk vægtigere undersøgelse af de til de teoretiske hørende teleologiske dommes mulighed, som oprindeligt ikke engang hørte med til den planlagte "Kritik af smagen" (brev til Schütz, 1787), og som Kant i sit forord endnu betegner som 'vedhængt'. Både de æstetiske og de teleologiske domme er reflekterende, dvs. de søger til det empirisk givne et alment apriorisk princip, som alene kan stamme fra dømmekraften selv. Dette er princippet om genstandens formålstjenlighed, som kan forstås enten i ren subjektiv henseende, idet genstanden i overensstemmelse med det almengyldige, men ikke objektive 
smagsbegreb dømmes som skøn, eller i objektiv henseende, idet genstanden dømmes som mulig i kraft af en formålsmæssig årsag, hvilket appliceret på naturen som sådan kunne synes at muliggøre en fysisk-teleologisk begrundelse af teologien (i egentlig forstand metafysikkens fremskridt), hvilket Kant imidlertid korrigerer derhen, at en sådan begrundelse, som måtte bevise eksistensen af den formålsmæssige årsag uden for naturen selv, nødvendigvis forudsætter resultatet af det eneste mulige, nemlig moralsk-teleologiske og alene subjektivt gyldige Gudsbevis med udgangspunkt i nødvendigheden af muligheden af virkeliggørelsen af det højeste gode $i$ verden. Med denne nøje afstemmelse i form af en ifølge Kant subjektivt gyldig forbindelse mellem forstandens naturlovgivning og fornuftens moralske lovgivning for friheden ender dette af så mange vidt forskellige bestræbelser på afslutning, fuldstændighed og enhed gennemtrængte og derfor for den filosofiske læsning ekstremt anstrengende og til alle tider udfordrende værk.

Det er lykkedes oversætteren at bringe Kants ofte komplicerede sætningskonstruktioner over $i$ et flydende, moderne dansk. Det sker desværre ikke altid uden tab af mening, hvilket dog kun sjældent resulterer i det direkte modsatte af Kants intention. Et enkelt eksempel herpå er oversættelsen af den første maksime i dømmekraftens antinomi: "Enhver frembringelse af materielle ting og deres former skal udelukkende bedømmes som mulige efter mekaniske love" (s. 216), hvilket faktisk ville umuliggøre Kants efterfølgende opløsning af antinomien (læs derfor: "Enhver frembringelse af materielle ting og deres former skal bedømmes som mulig[sic!] efter blot mekaniske love"). En anden graverende fejl: Syv gange i løbet af bogen oversættes eller forveksles Kants 'Teleologie' med 'teologi', hvilket ikke er tegn på stor forståelse for tankegangen $i$ anden del af værket. Oversætterens faktuelle anmærkninger inddrager bl.a. en række citater fra Hume, Burke og Baumgarten som baggrundsdokumentation for Kants diskussion. Til gengæld får vi andetsteds at vide, at Rousseau er ophavsmand til udtrykket 'anden natur' (s. 119), som dog før Rousseau i det mindste findes hos Pascal (Tanker nr. 120). En anden note beretter, at "Kant følger Linné og bruger species (...) som undergruppe til genus (...)" (s. 44), medens der er tale om ganske traditionel filosofisk sprogbrug. Endelig forklarer en note, at Kants 'vernünfteltes Wesen' betyder “et væsen, der ikke skelner mellem tænkning og erkendelse" (s. 288), hvor der dog er tale om en tysk gengivelse af 'ens rationis ratiocinantis' (i senskolastisk terminologi $=$ en tanketing uden fundament $i$ virkeligheden, dvs. hvis objektive realitet på ingen måde kan godtgøres, som Kant ville sige; dette til forskel fra 'ens rationis ratiocinatae' $=$ en tanketing med fundament $\mathrm{i}$ virkeligheden, som Kant her kalder for 
et 'Vernunftwesen'). Oversættelsesnøglen bag $\mathrm{i}$ bogen er upræcis og $\mathrm{i}$ det hele taget redigeret noget sjusket (bl.a. stavefejl i flere tyske ord), og størstedelen af de opførte oversættelsesvalg gengiver rene dagligdagsord uden betydning for Kants filosofiske terminologi. Hvad angår særlige valg på det terminologiske plan, så forekommer først og fremmest oversættelsen af 'Dasein' med 'derværen' (og nogle gange med 'væsen' og 'derværende') meget lidt efterfølgelsesværdig. 'Dasein’ bør konsekvent oversættes med 'eksistens', når nu Kant bruger de to ord synonymt, og 'derværen' på sin side ikke er et dansk ord, men en misforstået fordanskning af et tysk dagligdagsord, som først Heidegger ved et retorisk kneb for en kort overgang gjorde til en filosofisk fagterm. Hvor 'eksistens' ikke synes træffende, kan man i stedet tale om 'tilværelsen' ( $\mathrm{fx}$ kan man måske bedre glæde sig over, at man er til, end over, at man eksisterer). Præsentationen af dette værk er ikke på højde med samme udgivers presentation af Kritik af den rene fornuft. Hvor prisværdigt hele foretagendet altså end er, vil et andet, stærkt forbedret oplag være prisværdigt.

Claus Asbjorn Andersen

\section{Men er Foucault filosof?}

Anders Fogh Jensen: Mellem ting. Foucaults filosofi. Det lille forlag, 2005. 352 sider, kr. 320,-

Denne introduktion til Foucault er usædvanligt god. Den vil på flere måder være til gavn for alle med interesse $\mathrm{i}$ spørgsmålet om ledelsesformernes historie - det punkt, hvor Foucault nok er mest uundværlig for forståelsen af 'nutidens historie', som han sagde.

Selv om det ikke siges meget tydeligt, er bogens projekt at rekonstruere Foucault ud fra det synspunkt, han anlagde på sit forfatterskab i dets sidste del-dvs. ud fra den historiserende interesse i problematisering, ledelse og subjektivering, som udgivelsen af hans forelæsninger har kastet nyt lys over. Overordnet beskriver Anders Fogh Jensen Foucaults projekt med titlen på hans lærestol ved Collège de France som 'tankesystemernes historie', hvori er indbefattet 'styresystemernes historie' (ledelsesproblematikken). Det skaber plads til, at hele Foucaults forfatterskab kan rummes.

Dette udgangspunkt forekommer mig at være en rigtig god idé. Efter selv at have forsøgt at begribe forholdet mellem Foucaults stadige genfortolkning af sit forfatterskab og dets udvikling i den historiske kontekst er jeg kommet til det foreløbige resultat, at Foucault i sine sidste genfortolkninger faktisk nåede frem til en stadig mere omfattende forståelse af sit projekt. Ikke fordi han hele tiden 